\title{
Research on New Model of Business English Negotiation Talent Cultivation Based on Flipped Classroom Mode
}

\author{
Dan Xu \\ Faculty of International Studies, Henan Normal University, Xinxiang, China \\ Email: x_dan@foxmail.com
}

How to cite this paper: Xu, D. (2019) Research on New Model of Business English Negotiation Talent Cultivation Based on Flipped Classroom Mode. Open Journal of Business and Management, 7, 1577-1585. https://doi.org/10.4236/ojbm.2019.74109

Received: July 15, 2019

Accepted: August 6, 2019

Published: August 9, 2019

Copyright $\odot 2019$ by author(s) and Scientific Research Publishing Inc. This work is licensed under the Creative Commons Attribution International License (CC BY 4.0).

http://creativecommons.org/licenses/by/4.0/

\section{(c) (i) Open Access}

\begin{abstract}
The new teaching model of flipping classrooms has been widely used in business English negotiation talents in recent years. With the valuable time in the classroom, students can concentrate more on active project-based learning, jointly study and solve the challenges of localization or globalization and other real world problems, thus gaining a deeper understanding. Teachers no longer occupy classroom time to teach information, which requires students to complete autonomous learning before class. They can watch video lectures, listen to podcasts, read enhanced e-books, and discuss with other students on the Internet, and access the required materials at any time. Teachers can also have more time to communicate with everyone. This model subverts the traditional teaching mode and is loved by teachers and students. Through the application of flipped classroom in business English negotiation course teaching, this paper draws a conclusion that flipped classroom is very helpful to the smooth development of business English negotiation classroom activities and to the improvement of learners' autonomous learning ability and business negotiation skills in the process of training business English negotiation talents.
\end{abstract}

\section{Keywords}

Flipped Classroom, Business English Negotiation, Self-Learning, Negotiation Skills

\section{Introduction}

The development of the Internet+ era and the increasing activity of international trade activities have promoted the further development of international business English negotiation activities. Successful international business English negotia- 
tion largely affects the economic exchanges between countries and determines the rise and fall of the enterprise. Therefore, the training of business English negotiation talents is very important, which further highlights the importance of business English negotiation courses [1]. The background of the Internet+ era has spawned a new teaching model of flipping classrooms, which will subvert the process of knowledge transfer and internalization. By applying the flipping classroom to the course of Business English Negotiation, we can truly realize the goal of cultivating the curriculum of modern international business English negotiating talents with heavy practical skills, heavy skills and intercultural communication skills [2].

\section{The Connotation of Flipped Classroom}

Flipped Classroom is also called inverted classroom or inverted classroom. It is a kind of teaching form that uses technical means to impart knowledge asynchronously, liberate classroom practice and develop student-centered individualized teaching activities. It is also a kind of teaching form that integrates online learning and classroom teaching in order to achieve the best results [3]. Specifically, it reverses the process of "classifying knowledge and internal knowledge" and "internal knowledge and class internalization knowledge" in the traditional teaching mode, forming a new teaching mode, and then the teacher provides a personalized teaching environment, which also increases the interaction time between teachers and students, improves the students' self-learning ability, and truly realizes the teacher's "supervision" and "guidance" role.

The budding stage of the flipped classroom can be traced back to the US West Point Military Academy in the mid-19th century. The school sent the teaching materials to the students in advance during the teaching process, and encouraged the students to discuss and solve the problems raised by the students. The development stage of flipped classroom is the establishment of Khan College Channel on YouTube in 2004. The college recorded all the lecture materials needed in class and uploaded them to the website for students to study before class. This teaching method has achieved good teaching effect and caused great social repercussions. With the rapid development of information technology and the emergence of the Internet+ large teaching environment, the flipped classroom has entered the promotion stage, which has promoted the rapid transition of traditional teaching to personalized teaching [4].

\section{Problems in the Teaching of Business English Negotiation Courses}

The training mode of traditional business English negotiating talents has seriously fallen behind the development of the information society. There are problems such as outdated teaching mode, limited teacher level and lack of enthusiasm for students' learning [5]. The specific manifestations of these issues are discussed below. 


\subsection{Outdated Teaching Mode}

In the traditional business English negotiation classroom teaching, the emphasis is on the explanation of theoretical knowledge, while neglecting the improvement of practical ability. The classroom is always dominated by teacher's explanations, and students are basically in a passive listening situation. The interactive method is single and the interesting is weak. Even with the better case teaching methods such as communicative teaching method and problem-oriented teaching method, due to the lack of application space, it is only in static case analysis. Moreover, due to the limited classroom time, many courses are content-based. Students cannot fully comprehend in class, and there are few opportunities to really participate in the classroom, which leads to boring classroom, students' lack of concentration and gradually lose interest in the curriculum.

\subsection{Limited Teacher Level}

Most of the teachers who teach business English negotiation courses graduated from English majors and have a solid foundation in English language. However, the accumulation of professional knowledge in economics and trade is not enough. Many teachers have little or no experience in corporate work. Therefore, in the course of classroom teaching, it is basically based on the textbook, which leads to some knowledge points in the course are not thoroughly explained, it is difficult to effectively combine the basic negotiation theory with the practical cases. However, the development of business English must be compatible with the development of the times, and can make correct judgments based on objective reality. Business English negotiation teaching that is out of touch with reality cannot make students grasp the essence of business negotiation courses, and it is not conducive to improving students' business negotiation skills.

\subsection{Students Lack Enthusiasm for Learning}

After all, business English negotiation is a professional course, which is more difficult and boring than the ordinary English course. All the problems that puzzle students in the process of learning ordinary English, such as listening, writing and oral English, are also puzzling their study in business English negotiation course, which leads to students failing to keep up with teachers' rhythm in class and failing to understand the theoretical basis of business negotiation. It greatly reduces the students' enthusiasm for learning.

\section{Feasibility Study on the Application of Flipped Classroom in Business English Negotiation Course Teaching}

In order to make up for the shortcomings of the traditional business English negotiation talent training mode, this paper proposes to apply the new teaching method of flipped classroom to the teaching system of business English negotiation course. The feasibility of the teaching and training model is demonstrated from three aspects: the training objectives of business English professionals, the 
setting of business English courses and the enthusiasm and initiative of students.

\subsection{Reflecting the Training Goal of Business English Professionals}

In 2015, the business English professional talent training program pointed out that business English professionals need to have solid basic English skills, master a variety of knowledge, and be proficient in applying English, mastering business practice ability and intercultural communication ability and thinking and innovation ability. Based on the Internet+ the new teaching mode of the new teaching mode-flipping the classroom, it provides a new way for the implementation of the business English professional training objectives of colleges and universities. In this new teaching mode, teachers use the Internet platform to create different types of visual teaching videos in advance of the key and difficult points in the course. Students are required to watch these videos before class to learn independently and to learn the knowledge imparted in the traditional teaching mode in advance. In this process, students can improve their basic knowledge of English and their ability to learn independently and innovate. By watching videos of other relevant knowledge on the Internet platform, students can get a good understanding of business English negotiation cases at home and abroad, thus promoting students to develop the habit of looking at problems from multiple perspectives and thinking ability. In order to better grasp the business English negotiation knowledge and improve the practical ability to lay the foundation, and to make full preparations for the future road to real international business English negotiation.

\subsection{Promote the Implementation of Business English Curriculum}

With the continuous development of international trade, the demand for international business English negotiating talents with higher professional level is also growing in China, and the voices of students and society in setting up business English negotiation courses in colleges and universities have also increased. However, the business English negotiation textbooks adopted by many universities in China are relatively theoretical and boring, and the basic teaching methods are traditional, which makes it difficult for students to concentrate on their classes and their attitudes are not positive. The selection of teaching materials related to business English negotiation and the setting of courses are generally separated from the actual needs of students. In addition, the arrangement of such courses is less relevant to the society, which is not conducive to the true cultivation of students' professional practice ability. The scientific introduction of the new teaching mode of flipped classroom enables students to watch videos of micro-courses and curtain courses related to business English negotiation courses on the network platform, which are suitable for themselves. They no longer rely entirely on the limited teaching resources of teachers and schools. They can also learn more relevant knowledge and master it after class. Major cases related to the course and the application of what we have learned to the classroom and practice greatly meet the learning requirements of students to 
improve their practical ability in business English negotiation.

\subsection{Inspire Students to Learn Enthusiasm and Initiative, and Create a Variety of Teaching Methods}

China's flipped classroom is still in the process of exploration and practice, but students and teachers who have experienced the new teaching model have made high praises for it, and hope that the school can further reform the future teaching model. The new teaching model based on advanced information technology has greatly changed the role and status of students and teachers in traditional classrooms. The traditional teaching mode emphasizes the dominant position of teachers in the whole teaching process, pays more attention to the classroom and its teaching content, neglects the independent role of students in the learning process to a certain extent, and lacks certain supervision to students' learning before and after class.

As a product of the development of information technology, the emergence and development of flipped classrooms have had a tremendous impact on traditional teaching models. The flipped classroom teaching mode provides students with a platform for self-learning. Students need to consciously complete the curriculum-related knowledge that they have learned in the classroom before class. Students can participate in the classroom with problems, and they can fully participate in the classroom and improve the efficiency of the class. It not only completes the process of knowledge internalization better, but also greatly improves students' autonomous learning ability and innovation ability [6]. Many domestic students have also confirmed the feasibility of flipping the classroom teaching mode to enhance students' self-management learning ability, motivate their learning motivation and independent learning behavior. Scholars also found this by comparing traditional teaching with flipped classroom teaching, that is, flipping classroom teaching can effectively stimulate and cultivate college students' self-learning motivation and cooperative learning ability [7]. In the flipped classroom teaching mode, the teacher's central position has also been changed, truly becoming a student's academic advisor, a scholar, not just a transmitter of knowledge. Applying the flipped classroom to the teaching process of the business English negotiation course, the cooperation in the teacher and student classroom has successfully created a variety of new teaching methods such as business case teaching method and business English negotiation simulation teaching, which has created a strong sense. The atmosphere of thinking and communication effectively stimulates students' participation and creativity in the classroom.

\section{The Specific Application of Flipped Classroom in the International Business English Negotiation Course}

In order to apply the flipped classroom to the international business English negotiation course and give full play to its role, we must first consider the issue of teachers [8]. In view of the lack of professional knowledge and practical experience of the business English negotiation course teachers, teachers can enter the 
counterpart foreign trade enterprises to carry out their job training, participate in the real project of foreign trade enterprises, such as the formulation of negotiation plan books, the formulation of negotiation contracts, and other specific negotiating work matters. It also summarizes the experience in the process of business English negotiation, and organically combines various negotiation theories and negotiation practices in the actual teaching in the future, and activates the classroom atmosphere. At the same time, teachers should change the original teaching methods and cite the advanced teaching mode-flipping the classroom, truly let the students move, organically combine "doing" and "learning", improve classroom efficiency, and stimulate students' enthusiasm and creativity. Cite best practices????

\subsection{Analyze the Reality of Students}

Under the new teaching mode of flipped classroom, the roles of teachers and students have changed, and students have become the main body of the classroom. How to stimulate students' knowledge and desire for knowledge largely determines the enthusiasm of students' independent students. Therefore, teachers should understand the existing knowledge structure and foundation of students in advance, and formulate teaching plans and teaching goals suitable for students according to the characteristics of students, and set teaching tasks with moderate difficulty. At the same time, before each class, the teacher informs the students in advance of the basic content and related training involved in the class in order to improve the participation of the students in the class.

\subsection{Determining the Teaching Objectives of the Flipped Classroom}

After analyzing the actual situation of the students, the teacher can determine the teaching objectives of each unit, and further subdivide the classroom content of each unit to guide the students to determine the content and tasks of the instructional video before the class, such as business negotiations. The professional terminology, the basic theory of negotiation and the negotiation process are related to the knowledge content of the business English negotiation course, so that students can master the primary knowledge independently. In the classroom, the teacher explains according to the difficult points raised by the students in the process of watching the video. At the same time, let students simulate the business negotiation process in the classroom, which not only improves the efficiency of the classroom, but also realizes the internalization of knowledge and enhances the students' enthusiasm for learning and the cultivation of thinking ability. This hierarchical learning goal setting makes it easier for students to clarify the specific learning objectives and tasks of each unit, and then gradually learn the relevant knowledge of business English negotiation and master business negotiation skills [9].

\subsection{Arrangement of Pre-Class Tasks}

The new teaching mode of flipping the classroom will be carried out by the stu- 
dents themselves before the class is transferred to the class. However, in this process, instead of simply watching the learning video materials provided by the teacher, the students should learn creatively and watch the video with the teaching tasks and questions raised by the teacher. And carefully watch and read the business negotiation case materials related to the contents of this chapter, learn the materials and ask their own questions. In this way, we will actively participate in the classroom; teachers can also answer questions according to the specific situation of students' self-learning before class, which not only improves the efficiency of the classroom, but also stimulates the students' enthusiasm for learning.

\subsection{Designing Classroom Activities}

Under the flipped classroom, the teaching of basic knowledge has been moved to the class, so the design of classroom activities has become the central link in the flipping classroom. Students have already learned the basics of this chapter before class, which has freed up a lot of time for class activities. In order to make full use of classroom time, the design of classroom activities is especially critical, to be reasonable, full, and orderly.

On the one hand, for the common problems raised by students in the process of watching teaching video materials before class, teachers can guide them to encourage students to discuss and explore, so that students can achieve a sense of accomplishment and enthusiasm for participating in the classroom. On the other hand, for the personality problem in the business negotiation process, the teacher can conduct group discussion, group competition, and simulation business negotiation process to train students' teamwork spirit and dialectical thinking ability. In the process, the teacher always plays the role of "consultant" who reviews the various performances of students, analyzes their strengths and weaknesses, and makes it easier for students to master and internalize the content of this chapter [10].

\subsection{Feedback of Classroom Effect}

Timely feedback on the teaching content of each class is more conducive to students to find their own short board. On the one hand, from the perspective of students, we can design some questions about the content of each chapter, such as what students have learned from this lesson, and whether this teaching method makes it easier for students to understand the contents of this chapter. On the other hand, through the knowledge discussion and case analysis of the students in the classroom, the students' self-learning and the knowledge content of the class are observed, and the performance of the students' knowledge application process is recorded, summarized, and guided in time [11]. Help students to master the knowledge points and practical application skills of each chapter more effectively.

\section{Conclusion}

As a product of the development of information technology, flipping the class- 
room breaks the traditional teaching mode and pays more attention to the leading role of students in the whole learning process. The flipped classroom model emphasizes that students can independently and creatively watch the instructional videos uploaded by the learning teachers before the class, as well as other videos on the business platform for business English negotiation on the online platform, and ask questions. The teacher sets the teaching tasks and goals according to the students' basic conditions, rationally designs the classroom activities, encourages students to fully participate in the classroom activities through group discussion and simulation of all aspects of business English negotiation, and makes timely and targeted feedback to the classroom activities. The application of flipped classroom teaching mode in business English negotiation course can help students improve their autonomous learning ability and creative thinking, grasp the essence of business negotiation course, truly improve their practical skills in business English negotiation, and become professional business negotiation talents.

\section{Conflicts of Interest}

The author declares no conflicts of interest regarding the publication of this paper.

\section{References}

[1] Tratnik, A., Urh, M. and Jereb, E. (2019) Student Satisfaction with an Online and a Face-to-Face Business English Course in a Higher Education Context. Innovations in Education and Teaching International, 56, 36-45. https://doi.org/10.1080/14703297.2017.1374875

[2] Siqi, C. (2017) Integration of Three CBI Models and WeChat Mobile Learning in Business English Teaching. English Language Teaching, 10, 218-226. https://doi.org/10.5539/elt.v10n9p218

[3] Shinaberger, L. (2017) Components of a Flipped Classroom Influencing Student Success in an Undergraduate Business Statistics Course. Journal of Statistics Education, 25, 122-130. https://doi.org/10.1080/10691898.2017.1381056

[4] Chen, F., Lui, A.M. and Martinelli, S.M. (2017) A Systematic Review of the Effectiveness of Flipped Classrooms in Medical Education. Medical Education, 51, 585-597. https://doi.org/10.1111/medu.13272

[5] Ai, B., Wang, L. and Zhang, J. (2018) Using English as Economic Capital in a Chinese-Australian Workplace: Implications for Teaching Business English in China. Journal of Teaching in International Business, 29, 272-288.

https://doi.org/10.1080/08975930.2018.1557095

[6] Altemueller, L. and Lindquist, C. (2017) Flipped Classroom Instruction for Inclusive Learning. British Journal of Special Education, 44, 341-358. https://doi.org/10.1111/1467-8578.12177

[7] Lucardie, A.T., Berkenbosch, L., van den Berg, J., et al. (2017) Flipping the Classroom to Teach Millennial Residents Medical Leadership: A Proof of Concept. Advances in Medical Education and Practice, 8, 57-61. https://doi.org/10.2147/AMEP.S123215

[8] Wu, P. and Yu, S. (2017) Developing Pedagogical Content Knowledge (PCK) 
through Module Team Collaboration: A Case Study of Business English Teachers in China. The Asia-Pacific Education Researcher, 26, 97-105.

https://doi.org/10.1007/s40299-017-0330-9

[9] Esteban, A.A. and Cañado, M.L.P. (2004) Making the Case Method Work in Teaching Business English: A Case Study. English for Specific Purposes, 23, 137-161. https://doi.org/10.1016/S0889-4906(03)00016-4

[10] Adams, M. and March, S. (2015) Perezhivanie and Classroom Discourse: A Cultural-Historical Perspective on "Discourse of Design Based Science Classroom Activities”. Cultural Studies of Science Education, 10, 317-327. https://doi.org/10.1007/s11422-014-9574-3

[11] Nguyen, H., Xiong, W. and Litman, D. (2017) Iterative Design and Classroom Evaluation of Automated Formative Feedback for Improving Peer Feedback Localization. International Journal of Artificial Intelligence in Education, 27, 582-622. https://doi.org/10.1007/s40593-016-0136-6 